\title{
ABOUT SPELLS AND RECIDIVISM OF THE TRANSITION ECONOMIES' PARTICIPATION IN IMF PROGRAMS
}

\author{
Stepan Panchyshyn \\ Department of Analytical Economy and International Economics \\ Ivan Franko National University of Lviv \\ 1 Universytetska str., Lviv, Ukraine, 79000 \\ stmpanchyshyn@gmail.com \\ Iryna Hrabynska \\ Department of Analytical Economy and International Economics \\ Ivan Franko National University of Lviv \\ 1 Universytetska str., Lviv, Ukraine, 79000 \\ de.mandat@gmail.com
}

\begin{abstract}
Based on the review of the modern world economic literature, there were revealed polar approaches of researchers to estimation of the role of the International Monetary Fund (IMF) in world economic processes in whole and its influence on the economic development of separate countries. There were analyzed institutional changes in IMF architecture and management system that favored its transparency, efficiency and increase of trust to the activity of the Fund from the world society.

Based on the dynamic approach to the analysis of credit cooperation of countries-recipients with IMF, there were revealed factors that caused differences in duration of series of IMF lending programs (spell) for transition economies and ones that determine recidivism of their credit relations with the Fund. Among other ones, the determining role is played by the technical assistance of the Fund that favored institutional establishment of unstable economic systems, search for consensus between IMF staff members and governments of countries about formation of the policy of conditionality and effectiveness of its realization.

The article presents chronologization and analytic estimation of main stages of cooperation between Ukraine and IMF, estimates the net transfers of financial resources of the Fund, elucidates conditions of the incomplete drawn of granted credit resources by Ukraine, causes of finishing credit cooperation and transition to technical one at different stages. At the end there was made a conclusion that main efforts must be directed on constructing native economic system a self-sufficient macroeconomic pattern of the development of the native economic system.
\end{abstract}

Keywords: IMF programs, duration, spell, recidivism, policy of conditionality, economic stabilization, prolonged user.

\section{Introduction}

Publications in the world economic literature testify to the ambiguous estimation of IMF activity. Some economists think that it realizes an important function in the modern global economy, other ones argue that IMF became a non-representative, ineffective organization that induces moral risks, and the world would be better without it $[1,2]$.

Undoubtedly, IMF played an important role, in the world global economy for seventy years, especially as to the solution of problems of providing stability of national economies and international monetary-financial system in whole. The Fund is not only a source of external financial resources, but became a center of the elaoration, support and realization of a development strategy of developing countries. IMF acts as a confident adviser of a government, at that using the experience of other countries and information from power structures that they are not inclined to share with rating agencies and investment banks [3]. The combination of recommendations and financial resources help to accelerate processes of achieving macroeconomic stabilization.

At the same time, in last decades there are observed regular institutional changes in both institutional model of IMF functioning and relations between the Fund and countries-members. It is manifested especially in the duration of cooperation between countries-borrowers and the Fund. Separate countries demonstrate the high inclination to widen credit relations with IMF. Among factors that determine the duration and frequency of addresses of countries to IMF for credit support, economists especially underline the effectiveness of previous credit programs in providing mac- 
roeconomic stabilization. But the modern economic literature pays not enough attention to investigating factors that determine the duration of cooperation of the Fund with transition economies, especially, revealing causes that conditioned differences in the type of IMF participation in transformation processes, duration, scales and effectiveness of credit relations in post-Soviet countries.

\section{Aim of research}

The study of economic and institutional changes that determine the duration and frequency of cooperation between transition economies and IMF, and also causes that conditioned differences in the effectiveness and type of Fund's participation in processes of system transformation in these countries.

\section{Materials and methods}

The main results of the scientific research were obtained, based on using general scientific and special cognitive methods, especially:

- historical-philosophical, dialectic methods, analysis and synthesis - for revealing factors and results of the evolution of the institutional model of IMF functioning under conditions of intensifying processes of financialization of economy and global financial instability;

- generalization and systematization - at studying modern tendencies, manifested in the type of IMF cooperation with developing countries, its scales and factors that determine its duration, frequency and inclination of a country to widening credit cooperation with the Fund;

- principles of complementarity - at studying political, historical mental, social and economic factors of effective cooperation of the Baltic post-soviet countries with IMF in attaining macroeconomic stabilization and providing conditions of the further economic growth and revealing causes of the low institutional and economic effectiveness of cooperation between Ukraine and IMF;

- methods of collation and comparison - at studying peculiarities of methodological approaches to estimating the economic effectiveness of credit programs and technical assistance of IMF;

- methods of analysis of interconnections - at revealing the influence of credits, given by the Fund on processes of macroeconomic stabilization in Ukraine at different stages of cooperation;

- methods of regression and correlation analysis - for estimating the effectiveness of credit cooperation with IMF and influence of IMF credits on the dynamics of key macroeconomic parameters of Ukraine in 1994-2017;

- graphic and table methods - for visualization of the dynamics of credit cooperation between Ukraine and IMF and macroeconomic indications of the native economy and research results.

\section{Results}

During the last decades IMF position in the world financial architecture a bit changed - its activity became more transparent and understood for the external world. The Fund also demonstrated the ability to study its own experience and to introduce essential changes in instruments of control and mechanisms of giving credit resources, especially after the world financial crisis. During the last years the Fund faced new challenges, conditioned by processes of financialization and intensification of global financial instability. Distrust manifestation of the world community to the many-sided financial cooperation and activity of both national and international financial institutions became more often. It needed from IMF the critical reinterpretation and improvement of mechanisms of management and accountability realization that, according to coworkers and leaders of the Fund, favors trust strengthening.

For this aim there was created a series of institutions, that must provide transparency, effectiveness and to raise trust to the activity of such world organizations - in 1998 the USA congress created The International Financial Institution Advisory Commission, also known as Meltser commission, which main task is to produce of recommendations for forming the USA policy as to multilateral agreements of IMF, World bank group, bank of international calculations and WTO [4]. 
In 2001 there was created the special subdivision of IMF - (The Independent Evaluation Office (IEO). According to its authorities, it is completely independent from IMF leaders and must provide the independent and objective estimation of policy and activity of the Fund, its external credit solvency, transparent activity of the international financial institution and strengthening of leaders' responsibility for made political and financial decisions that, in its turn, favors strengthening of the external authority of the Fund, support of institutional management and legitimacy of the Fund among its stakeholders.

IEO in 2002 firstly published a report, studied causes of the growing duration of credit cooperation between separate countries-borrowers and IMF. This phenomenon finally causes anxiety in both countries - main creditors of IMF and in international financial community. One of conclusions, made by IOE specialists is that membership in IMF and active participation of members in its programs condition the long dependence of a borrower from IMF resources [5].

In 1950-1960 the duration of credit programs of IMF cooperation with countries-members was in average 1-2 years. But during the last decades of XX century, there was traced the increase of credit programs duration to three years, and the use of a series of them by separate countries during five and more years. Researchers think that main causes of the increase of such cooperation duration are more frequent bank and monetary crises, suffered by economic systems of different countries. The analysis of IMF credit programs for different countries demonstrated that the growth of duration and intensity of credit cooperation is typical, in first turn, for poorest countries with a great need in the external official support, landlocked ones, because their geographic location creates additional economic problems, and also countries which export structure mainly contains raw material goods. It is explained by the fact that they didn't succeed in creating their own industrial base for producing goods with a higher added value that is a source of the income growth [6].

One of most important factors that influence a frequency, duration and scales of credit cooperation with IMF is a dynamics of democratic and institutional transformations that take place in a country-recipient. Under conditions of a political crisis or acute ideological polarization of a society, the credit cooperation is usually not long, and a country-borrower doesn't take all costs, given by IMF, according to an accepted program. Such government cannot fully realize program requirements as to reforms. Countries with essential successes in democratization processes are more successful in implementation of program requirements as to economy reformation. Scales and duration of such cooperation programs are much shorter [7].

One more important cause of increasing duration of cooperation between countries and IMF, according to scientists, is a low income level, high level of sovereign debt and default threat. These countries usually have the limited access to the market of private financial capital. So, IMF is transformed in a permanent substitute of private capital markets [6]. The credit cooperation duration of almost one quarter of countries-IMF members (among them - Malawi, Uganda, Albania, Argentina, Armenia, Georgia and other) doesn't exceed $50 \%$ of time of their membership in IMF [8].

The Independent Evolution Office analyzed the duration of credit cooperation between countries and IMF and defined such category of countries-IMF borrowers as a prolonged user a country which during seven years of the last ten ones participated in IMF programs, within which volumes of given credits exceeded $100 \%$ of their quota. Typical fiscal determinants of such countries are the relatively low index of the ratio between tax incomes and GDP and state expenditure and GDP, high index of the ratio between the national debt and GDP, relatively low level of transparency of the economy, essential volume of the external debt. Among political determinants of countries-prolonged users there are named political instability, ethnic fractionalization and so on [5].

Most studies of participation of countries in IMF credit programs has a static character, within which there are usually studied the importance and presence of political and economic factors that condition participation or non-participation in IMF credit programs [9]. The dynamic approach in the study provides the empirical estimation of factors that determine the inclination of a country to spreading the use of IMF resources. 
That is why researchers in modern publications within the dynamic approach separate two dynamic components at the analysis of duration and effectiveness of countries' cooperation with IMF: Spell - duration of a continuous series of successive credit programs and recidivism indicator. Recidivism characterizes the inclination of a country to spreading credit relations with IMF, necessity of a country- IMF member to address it once more for financial help for solving problems of macroeconomic stabilization. Recidivism is measured by the duration of the period of time between series of credit programs of cooperation between IMF and a country-member-borrower $[6,10]$.

If participation in IMF credit program has a weak effect, the average duration of cooperation with it will increase. And vice versa, if credit resources, within a cooperation program of IMF, allow to achieve set aims - namely, to eliminate causes of worsening the state of the payment balance of a country, it can be expected that the duration of participation in future IMF programs will shorten.

If previous credit programs had a weak economic effect, recidivism of credit relations between IMF and a country-member strengthens, so the period of time between participation of a country in IMF credit programs shortens.

The analysis of empirical data gave scientists a possibility to reveal a certain analogue between country's participation in IMF credit programs and "revolving doors" [10]. A country enters a revolving door, takes part in one or several programs (continuous series of programs) of IMF, then came out of IMF participation. This experience may be repeated in some time. For countries with a little experience in working with IMF, these doors revolve slowly: the duration of a series of programs is relatively more, but the duration of a break in credit cooperation is also long. In countries with a large experience of working with IMF, revolving doors move faster. The duration of each next series of credit programs becomes shorter, but the one of the period between series of programs decreases also, so recidivism of credit cooperation grows.

During the last fifty years the overwhelming majority of developing countries became participants of credit cooperation programs of IMF and took a financial support from this international organization. Estimating IMF influence on transformation processes in countries of the Central-Eastern Europe, it must be noted, that stabilization programs of the Fund attained the set aim and gave positive results in Slovenia, Czechia, Hungry and Poland. These countries were first in the region that denied IMF financial support and started credit-free cooperation with the Fund.

For example, the Baltic countries in their time also used IMF financial support, they succeeded in avoiding deep political crises and obtained essential results in social democratization processes, so reformation of economic systems to become full members of the European Union. The duration of their cooperation with IMF varied from 3 to 5 years and became an effective instrument of macroeconomic stabilization and transformation reforms in 1990 - early 2000. The effective cooperation between IMF and the Baltic countries resulted not only in fast macroeconomic stabilization, but also conditioned the abrupt evolution of relations between them - transition from credit relations to technical assistance and preventive credit programs.

The crucial importance of the institutional development of economic systems of the Baltic countries was inherent to technical help, especially in financial, legal spheres and in statistics organization, given by IMF. Such help became a base of realization of the effective economic policy and structural reforms.

Native and foreign economists and politicians highly appreciate cooperation between the Baltic countries and IMF. The professional support as recommendations, formulated by IMF coworkers as to methods of macroeconomic stabilization, market transformation of the economic system, structural and institutional reforms, formation of the effective macroeconomic policy, possibility for countries to get the international support, to overcome internal political contradictions. The effectiveness of the work depends on how this help is considered by power bodies and government.

A guarantee of the effective cooperation between IFO and the Baltic countries is considered, first of all, as the presence of the collective memory about market economy in the society, great desire and also political will of power structures of a country to realization of effective transformation 
reforms, coincided with national interest of reintegration of the economy into the European Union. IMF recommendations as to the policy of economy stabilization were a result of debate, discussions and compromise and supported by power structures and politicians were successively implemented in the state economic policy and strategy.

It must be noted, that initial conditions of transformation reforms in post-soviet countries were essentially worse than in other post-communistic countries of the Central-Eastern Europe. The system shock, conditioned by the collapse of the centralized planning system, existed at the territory of the former Soviet Union, worsening of trade conditions because of the high energy dependence of former republics from Russia, conditioned essential disproportions in both real and monetary sectors of the economy [11]. Thus, trade conditions in the Baltic countries after USSR disintegration worsened by $20 \%$ that conditioned the decrease of real incomes. For comparison, the transformation shock conditioned GDP reduction by $5 \%$ in the countries of the Central-Eastern Europe.

Ukraine became a member of IMF in September of 1992 and its quota for that time was SDR $997 \mathrm{mln}$ (near 1.6 bil bln USD). The main aims of cooperation with IMF were stabilization of the native financial system, structural reforms in the economy and creation of a background for the sustainable economic growth. During 1992-2016 IMF had accepted decisions for giving Ukraine credits in the sum of 72.1 bil UDS, among which Ukraine really took only $21410.76 \mathrm{mln}$ SDR (equivalent of 31.6 bln USD) [12]. After the next (fourteenth) revision of quotas of IMF country-members that had taken place in 2016, Ukraine received a confirmation of increasing its quota from $1372 \mathrm{mln}$ SDR to $2011.8 \mathrm{mln}$ SDR (near $2.8 \mathrm{bln}$ USD) [13]. It allowed it to decrease payments for using IMF resources.

At the same time cooperation with IMF opened for Ukraine possibilities to involve financing from other international financial organizations (World bank, EBRD, EIB), governments of other states - USA, Germany, Japan, Canada and so on. Obtaining credits by Ukraine from IMF is a kind of indicator for the development of mutual relations with other international financial organizations.

For today main requirements of IMF to Ukraine for finishing the current program of EFF (Extended Fund Facility) is acceptance of the pension reform, creation of anticorruption courts, transparent privatization, and also introduction of the automated mechanism for regulating tariffs for gas and heat energy [14]. The history of credit cooperation between Ukraine and IMF testifies that the main aim of given credits was the support of the national currency rate and financing the deficit of the payment balance of Ukraine and filing of monetary reserves of the National bank of Ukraine. The first series of credit programs of IMF for Ukraine lasted mostly (1994-2002) - eight years. After that there was a break in credit relations, lasted for 7 years. The following series of credit programs was in 2008-2010 - period of deployment and overcoming results of the world economic crisis (3 years); after that there was a break - for three years. The next stage of cooperation 2014-2018 - is the period after the finish of the Dignity revolution and deployment of the great economic crisis in Ukraine on the background of Russian aggression in the East of the country. The chronicle of credit relations mainly confirm the results of previous studies that the increase of the experience of cooperation between a country and IMF favors shortening of each next series of credit programs, and duration of the period between series of programs also decreases, so recidivism of credit cooperation increases. But there must be taken into account the peculiarity of cooperation between Ukraine and IMF - breaks in credit relations were mainly forced, Ukraine couldn't take given costs completely mainly because of unrealized conditions of programs by it. The last program of cooperation with IMF, planned for 2015-2018, but really interrupted in spring of 2017, turned out to be the most effective. Ukraine received just four tranches for one program, the record sum - near 8.7 USD of expected 17 bln USD. The matter is that none previous credit program was finished by the complete realization of admitted liabilities by Ukraine and complete payment of the whole sum, provided by the program. As a result Ukraine didn't receive more than a half of the credit sum, provided by the Fund. There was no case, when Ukraine succeeded in agreeing about the next program to continue credit cooperation. 
Because of the wide inclusion of countries in IMF credit programs, there appeared a question about their effectiveness and contribution in economic growth processes. Authors of the foreign and native economic literature offer a series of methodological approaches to estimating the effectiveness of such cooperation. In first turn economists try to estimate the direct influence of financial help on the economic growth and other parameters of the economic activity. But realization of the objective analysis faces essential methodological complications. The matter is that countries-IMF members address for financial help only when their economies suffer from shortterm problems, connected with regulation of results of the external imbalance and in periods of macroeconomic destabilization.

Based on empirical data about the dynamics of GDP and participation of 130 countries in IMF credit programs during 1975-2000, researchers conducted the regression analysis of the influence of IMF credit help on the economic growth. It gave grounds for a conclusion that participation of countries-IMF members in credit programs had a negative influence on the economic growth. At the same time, received credits induce weak negative impulses on the development of democracy and rule of law in countries-recipients [15].

As a result of the conducted regression analysis for 20 countries with the transition economy (Albania, Byelorussia, Bulgaria, Bosnia and Herzegovina, Estonia, Latvia, Lithuania, Macedonia, Moldova, Poland, Russia, Romania, Serbia and Montenegro, Slovakia, Slovenia, Hungry, Ukraine, Croatia, Czechia) researchers didn't reveal any direct influence of IMF credits on such parameters as unemployment level, gross internal savings, joint expenditures of a state, GDP increment, export of goods and services, index of the real exchange rate. It testifies to the insufficient effectiveness of the mechanism of giving and using IMF credits in the development of the production sphere, innovative activity, regulation of state expenditures, influence of the structure and growth of GDP [16].

From our point of view, an approach to estimating the effectiveness of cooperation between IMF and Ukraine, based on the analysis of the modified four-factor production function for the Ukrainian economy, that includes labor, capital, institutional index among factors, creating incomes, and IMF credits as an additional factor, is interesting. Based on the econometric estimation of the contribution of each factor in the process of incomes creation, there was made a conclusion that the factors of capital and labor make a positive contribution in GDP production, whereas one of IMF credits has a positive, but very unessential role. It gave grounds to decline a hypothesis about the stimulating influence of IMF credits on the economic growth [17].

The analysis of the contribution of IMF credits in the dynamics of key macroeconomic parameters of Ukraine at different stages of cooperation gave a possibility to make ambiguous conclusions.

Thus, at its primary stages GDP credits really had an important positive influence of the GDP dynamics and other macroeconomic parameters. But where the period of loan repayment began and pure transfers of financial flows from IMF decreased even to negative values, the positive dependence decreases or even became negative. Exceeded rates of the increment of payments for given IMF credits over GDP growth rates mean that the stimulating influence on the total demand is exhausted (Table 1, Fig. 1-3).

IMF credits, received by Ukraine in crisis periods (Fig. 1), became an important factor of increasing gold-monetary reserves of the country, so favored the increase of the external liquidity and trust of foreign partners to the financial stability of the Ukrainian economy.

As it is testified by the empirical data, presented in Table 1, Fig. 2 and regression analysis results (Table 2) Ukraine doesn't demonstrate the influence of IMF credits on the economic growth. In such analysis it is expedient to take into account other factors with the essential influence on its dynamics - namely the conjuncture at world product markets that play a key role in the export goods structure (especially, agricultural products, black and color metals), negative influences of the world financial crisis of 2008-2010, occupation of Crimea and war at Donbas, resulted in losses of the essential part of the industrial potential of the country, and not very effective policy of NBU and Cabinet Council. 
Table 1

IMF loans and main macroeconomic indicators of Ukraine, 1994-2017 years

\begin{tabular}{|c|c|c|c|c|c|c|c|c|c|}
\hline Year & $\begin{array}{l}\text { Amount of } \\
\text { received } \\
\text { creditmln } \\
\text { SDR }\end{array}$ & $\begin{array}{l}\text { Payment of } \\
\text { interests and } \\
\text { commisions, } \\
\text { mln SDR }\end{array}$ & $\begin{array}{c}\text { Repayment } \\
\text { of credit } \\
\text { body, mln } \\
\text { SDR }\end{array}$ & $\begin{array}{c}\text { Net } \\
\text { transfer, } \\
\text { mln SDR }\end{array}$ & $\begin{array}{c}\text { State } \\
\text { (public) } \\
\text { external } \\
\text { debt to } \\
\text { GDP } \\
\text { ratio, \% }\end{array}$ & $\begin{array}{c}\text { GDP, mln } \\
\text { USD }\end{array}$ & $\begin{array}{l}\text { Real GDP } \\
\text { growth } \\
\text { rate (\% of } \\
\text { previous } \\
\text { year) }\end{array}$ & $\begin{array}{c}\text { Inflation rate } \\
\text { (December } \\
\text { to December) } \\
\%\end{array}$ & $\begin{array}{c}\text { Bal- } \\
\text { ance of } \\
\text { current } \\
\text { account, } \\
\% \text { of } \\
\text { GDP, \% }\end{array}$ \\
\hline 1994 & 249.3 & 0.04 & 0 & 249.2 & 9.18 & 52549.56 & -22.9 & 401 & -2.4 \\
\hline 1995 & 787.9 & 27.5 & 0 & 760.4 & 17.04 & 48213.87 & -12.2 & 181.7 & -3.2 \\
\hline 1996 & 536.0 & 51.3 & 0 & 484.8 & 19.57 & 44558.08 & -10.0 & 39.7 & -2.7 \\
\hline 1997 & 207.3 & 74.1 & 0 & 133.2 & 19.14 & 50150.4 & -3.0 & 10.1 & -2.7 \\
\hline 1998 & 281.8 & 84.8 & 77.3 & 119.7 & 26.48 & 41883.24 & -1.9 & 20. & -3.0 \\
\hline 1999 & 466.6 & 80.7 & 407.0 & -21.1 & 39.52 & 31580.64 & -0.2 & 19.2 & 3.0 \\
\hline 2000 & 190.1 & 92.5 & 643.5 & -545.9 & 33.1 & 31261.53 & 5.9 & 25.8 & 3.9 \\
\hline 2001 & 290.0 & 68.2 & 361.2 & -139.4 & 26.61 & 38009.34 & 9.2 & 6.1 & 3.7 \\
\hline 2008 & 3000.0 & 8.6 & 215.6 & 2776.8 & 10.27 & 179992.4 & 2.3 & 22.3 & -7.0 \\
\hline 2009 & 4000.0 & 87.4 & 57.3 & 3885.3 & 22.73 & 117227.8 & -14.8 & 12.3 & -1.5 \\
\hline 2010 & 2250.0 & 157.7 & 0 & 2092.3 & 25.48 & 136013.2 & 4.1 & 9.1 & -2.1 \\
\hline 2014 & 2972.7 & 38.6 & 2390.6 & 544 & 29.4 & 133503.4 & -6.8 & 24.0 & -3.4 \\
\hline 2015 & 4728.1 & 106.3 & 968.8 & 3653 & 47.9 & 91030.96 & -9.9 & 43.3 & -0.2 \\
\hline 2016 & 716.1 & 155.5 & 0 & 560.6 & 48.9 & 93270.48 & 2.3 & 12.4 & -1.4 \\
\hline 2017 & 734.1 & 220.4 & 628.8 & 115.2 & 43.7 & 112154.2 & 2.5 & 13.7 & -1.9 \\
\hline
\end{tabular}

Note: ${ }^{+}$- rate of dollar in Ukrainian karbovanets. Source: $[12,18,19]$

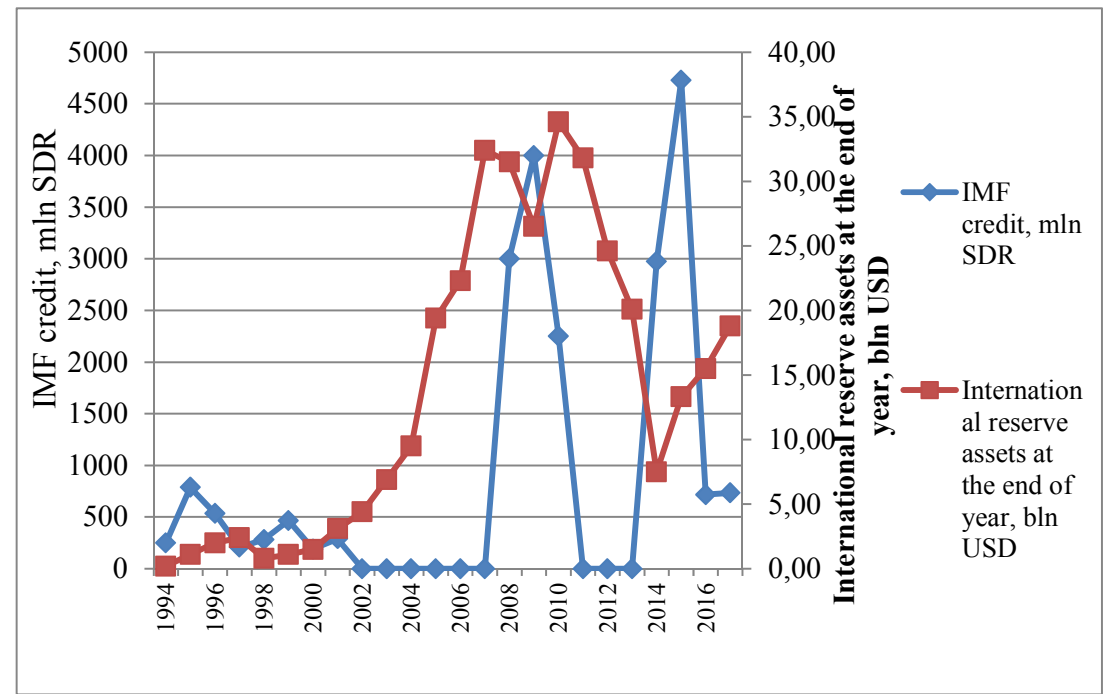

Fig. 1. Received IMF credits and international reserve assets of Ukraine, 1994-2017 


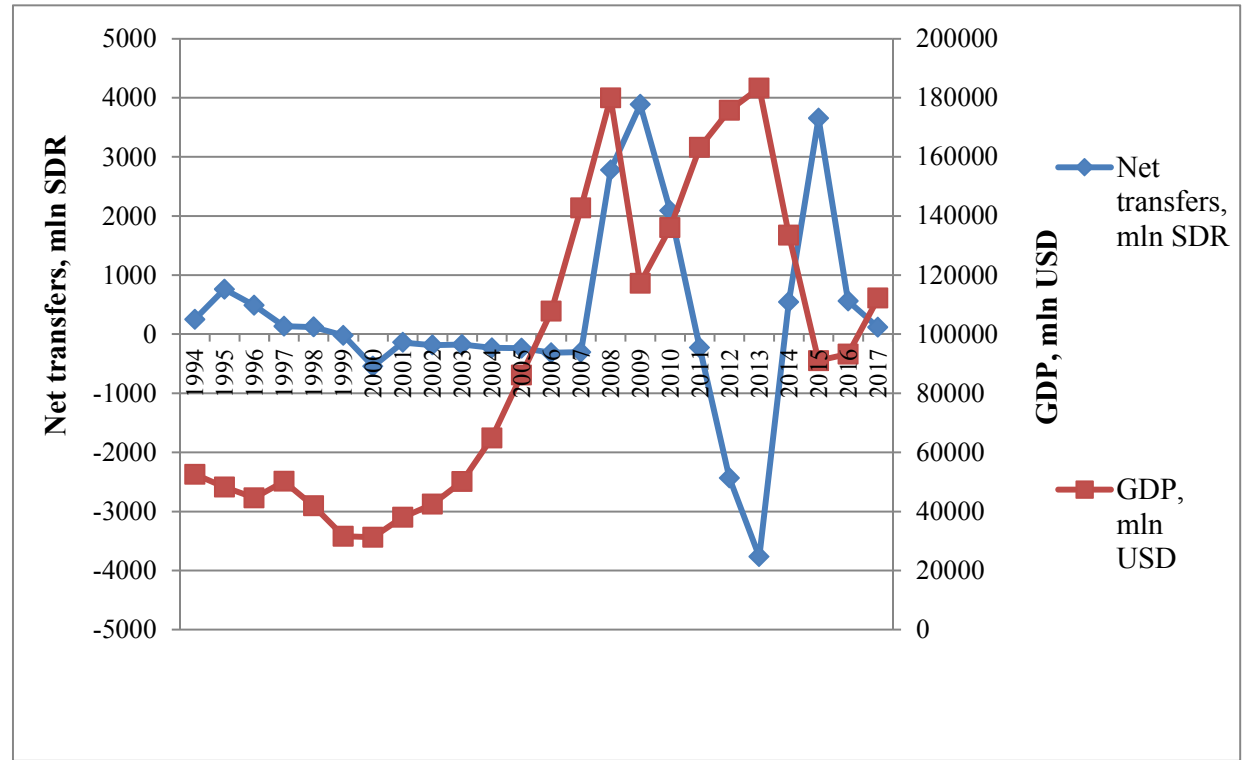

Fig 2. Net transfers of IMF credit resources and GDP of Ukraine, 1994-2017

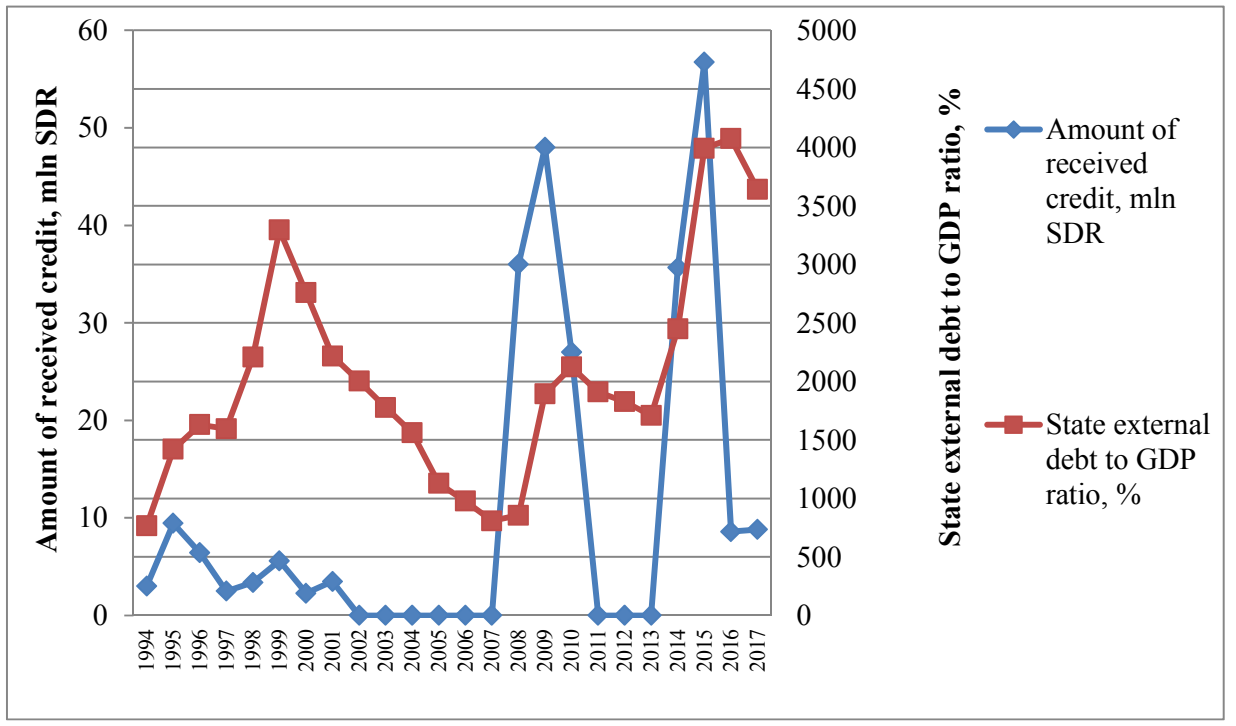

Fig. 3. Amount of received IMF loans and State external debt to GDP ratio, \% 1994-2017

The credit financing of IMF has an essential influence on formation of the external debt of Ukraine (Fig. 3, Table 2). Such tendency determines the increase of expenditures for its service and essential lead of external debt volumes as to international reserves of the country, so weakening of parameters of the debt stability of the state.

The regression analysis results and their testing for exactness, adequacy and validity give grounds to state that given IMF credits, taken by Ukraine, especially the pure transfer of credit resources is not a factor of the economic growth during the whole cooperation period.

It can be explained, especially by taking into account the specificity of financial resources, received from IMF - they usually have a short-term or middle-term character and are directed mainly on attaining the aim of macroeconomic stability that must be accompanied by reforms realization. Direct recipients of these resources are the sector of state management and bodies of monetary-credit regulation. Such credit resources are directed on the immediate overcoming of main macroeconomic disproportions in the economic system, caused by the deficit of state finances, lack of gold-monetary resources, growth of the external debt and decrease of the debt stability of the country. 
Table 2

Results of econometric estimation of the influence of credit cooperation between Ukraine and IMF on the economic growth, 1994-2017

\begin{tabular}{|c|c|c|c|c|c|c|c|c|c|c|c|}
\hline \multirow{2}{*}{$\mathbf{X}$} & \multirow{2}{*}{$\mathbf{Y}$} & \multirow{2}{*}{$\begin{array}{c}\text { Regression equa- } \\
\text { tion }\end{array}$} & \multirow{2}{*}{$\begin{array}{l}\text { Correla- } \\
\text { tion coef- } \\
\text { ficient }\end{array}$} & \multirow{2}{*}{$\begin{array}{c}\text { Coefficient } \\
\text { of determi- } \\
\text { nation } R^{2}\end{array}$} & \multicolumn{2}{|c|}{$\begin{array}{l}\text { d-Durbin-Wat- } \\
\text { son statistic }\end{array}$} & \multicolumn{2}{|c|}{ Student`s t-tes } & \multicolumn{3}{|c|}{ F-test } \\
\hline & & & & & d & $\begin{array}{l}\text { Auto- } \\
\text { correla- } \\
\text { tion }\end{array}$ & $\mathbf{T}^{\mathrm{em}}$ & $\mathbf{T}^{\mathrm{rr}}{ }_{\alpha}$ & $\mathbf{F}^{\mathrm{em}}$ & & $\mathbf{F}^{\mathrm{cr}}{ }_{\alpha}$ \\
\hline $\begin{array}{l}\text { Net transfers, } \\
\text { mln SDR }\end{array}$ & $\begin{array}{l}\text { GDP (mln } \\
\text { USD) }\end{array}$ & $Y=-2.3345 X+93064$ & -0.07 & 0.0055 & 0.2004 & added & 0.3552 & $<1.7171$ & 0.1852 & $>$ & 0.05 \\
\hline $\begin{array}{l}\text { Credit, } \\
\text { received from } \\
\text { IMF (mln } \\
\text { SDR) }\end{array}$ & $\begin{array}{l}\text { Balance of } \\
\text { current account } \\
\text { (\% of GDP) }\end{array}$ & $Y=-0.0006 X-0.0343$ & -0.19 & 0.0343 & 0.6438 & added & 0.9044 & $<1.7171$ & 0.7228 & $>$ & 0.05 \\
\hline $\begin{array}{l}\text { Credit, } \\
\text { received from } \\
\text { IMF (mln } \\
\text { SDR) }\end{array}$ & $\begin{array}{l}\text { Inflation rate } \\
\text { (December to } \\
\text { December), \% }\end{array}$ & $Y=-0.0019 X+39.401$ & -0.03 & 0.0010 & 0.4358 & added & 0.1528 & $>1.7171$ & 0.0289 & $<$ & 0.05 \\
\hline $\begin{array}{l}\text { Credit liabil- } \\
\text { ities for IMF } \\
(\mathrm{m} \ln \text { SDR }) \\
(1999-2017)\end{array}$ & $\begin{array}{l}\text { Gross external } \\
\text { debt for the } \\
\text { end of year (bil } \\
\text { USD) } \\
\text { (1999-2017) }\end{array}$ & $Y=4.7761 X-6942.6$ & 0.46 & 0.2199 & 0.9986 & added & 2.1829 & $>1.7396$ & 0.0001 & $<$ & 0.05 \\
\hline
\end{tabular}

So, the expected effect is indirect. At the same time IMF usually gives credits only subject to realization of arrangements of the rigid fiscal and deflation policy that, in their turn, condition the worsening of macroeconomic indicators in the nearest future. Under these conditions the expedience of analyzing the direct influence of the given credit cost on IMF on the economic growth is doubtful.

For guaranteeing the economic growth, Ukraine must not only receive IMF credits, but also needs the long-term financing as investments in the real economic sector. For today the credit cooperation with IMF has not already became a catalyst of the economic activity and trajectory of the sustainable economic growth of Ukraine that is a guarantee of the increase of the population welfare level.

\section{Discussion}

The chronology of credit relations between Ukraine and IMF mainly proves conclusions of previous studies about the effect of the Revolving door mechanism, manifested in fact that the duration of each next series of credit program (spell) shortens and the period between them decreases too, so recidivism of credit cooperation increases. But there must be taken into account the specificity of the type of cooperation between Ukraine and IMF - breaks in credit relations were usually forced. Ukraine couldn't withdraw funds, approved to it, in the full volume mainly because of non-realization of program conditions by it.

Ukraine as other transition economies needs involving credit resources from international financial organizations as a vitally important condition of providing macroeconomic stability, so the economic growth. Inability of the country to solve problems of financing, first of all, budget expenditures results in the fact that it takes new monetary costs as a debt, that becomes a part of its financial resources and due to correspondent economic mechanisms can influence the economic growth. But such instillations can have no positive results. A cause of such scenario can be both political and economic instability, negative shocks in world commodity markets, its government is 
unable to conduct the effective economic policy that is directly connected with the deepening of democratization processes in it.

Despite the differences in methodological and instrumental approaches to estimating the effectiveness of credit cooperation between developing countries and IMF, scientists made a conclusion about the absence of the essential positive influence of IMF credits on the economic growth in countries-recipients [15-17].

The estimation of the effectiveness of cooperation between Ukraine IMF presented in the article, proved the previous conclusions - there is traced no positive influence of given Fund credits on GDP, external debt level and other macroeconomic parameters of Ukraine for today.

Ukraine has not achieved the proper consensus with IMF specialists as to arrangements of macroeconomic stabilization and has not use their recommendations as to conducting structural reforms and institutional development of its economic system for today effectively.

Recommendations and requirements, set by IMF IMF staff members, which realization is a condition of the further financing of the Ukrainian economy often have no proper support among the population, different political forces and even power structures. That is why their realization has often formal, imperfect character, so is not a guarantee of the economic development.

Another cause of the low effectiveness is the unsteadiness of the Ukrainian economic system, manifested in defects of mechanisms of its functioning, namely - corruption, unreasonable use of involved resources, non-systematic accumulation of the state debt, resulted in essential threats as default or inflation and so on [20].

One of methodological problems that need further studying is the improvement formation of new approaches of analyzing the effectiveness of credit cooperation between transition economies and IMF, especially the use of adequate indicators for estimating the economic effectiveness of credit programs and technical assistance. In such analysis it is important to reveal directions of causative connections, to separate economic effects from the influence of other factors of macroeconomic stabilization and macroeconomic growth in a certain country. At the same time it is necessary to take into account political-institutional conditions of credit relations between a country and IMF. This approach will give a possibility to define determinants of spells and recidivism for transition economies.

\section{Conclusions}

1. A natural result of global processes of financialization of the world economy is evolutionary changes in the institutional model of IMF functioning, which, in their turn, provided the increase of the effectiveness of mechanisms of organizing accountability and management of the Fund, provision of transparency of its activity for the world community, increase of its competitiveness, strengthening of its authority and trust to it among stakeholders.

2. Among factors that determine a frequency and duration of credit cooperation between the Fund and transition economies is the experience of a country-recipient in cooperation with international financial organizations, economic effectiveness of previous programs, dynamics of democratic and institutional transformations, that take place in a country-recipient, indices of the sovereign debt stability of a country, implementation degree of technical assistance and IMF recommendations that favor macroeconomic stabilization, formation of the effective macroeconomic policy and institutional development of the economic system, political will and support of reforms, offered by the Fund, by power structures and wide layers of the population of a country-recipient.

3. The chronology of credit relations between Ukraine and IMF mainly proves theoretical conclusions that the increase of the experience in cooperation between a country and IMF often favors the decrease of duration of each next series of credit programs, and the period between them decreases too, so recidivism of credit cooperation increases. But the specificity of the type of cooperation between Ukraine and IMF - breaks in credit relations were usually forced. Ukraine couldn't take costs, given to it, in the full volume mainly because of non-realization of program conditions by it.

4. The econometric estimation of the influence of IMF credit help on indices of the macroeconomic dynamics in Ukraine for 1994-2017 gives grounds to state that the given credits didn't become a catalyst of the economic growth. Credit resources are directed on the immediate overcoming of main macroeconomic disproportions in the economic system, caused by the deficit of 
state finances, lack of gold-monetary resources, growth of the external debt and decrease of the debt stability of the country. The condition of giving such credits is realization of arrangements of the rigid fiscal and deflation policy that, in their turn, condition the worsening of macroeconomic parameters in the nearest future. Under these conditions the expedience of analyzing the direct influence of given credit costs on IMF on the economic growth is doubtful.

5. Recommendations and requirements of IMF, which realization is a condition of the further financing of the Ukrainian economy often have no proper support among the population, different political forces and even power structures, and their realization has often formal, imperfect character and doesn't favor the institutional development of the unstable economic system of Ukraine.

\section{References}

[1] Nissan, S. (2015). As Obituaries Are Written for the World Bank, the IMF is Set to Become Indispensable. Financial Times, beyondbrics.

[2] Eichengreen, B., Woods, N. (2016). The IMF's Unmet Challenges. Journal of Economic Perspectives, 30 (1), 29-52. doi: http://doi.org/10.1257/jep.30.1.29

[3] Reinhart, C. M., Trebesch, C. (2016). The International Monetary Fund: 70 Years of Reinvention. Journal of Economic Perspectives, 30 (1), 3-28. doi: http://doi.org/10.1257/jep.30.1.3

[4] The International Financial Institution Advisory Commission. Wikipedia. Available at: https:// en.wikipedia.org/wiki/International_Financial_Institution_Advisory_Commission

[5] Kaberuka, D., Meyersson, C. (2018). Time for a reboot at a critical time for multilateralism. The Third External Evaluation of the IEO, 68.

[6] Joyce, J. P. (2005). Time Past and Time Present: a Duration Analysis of IMF Program Spells*. Review of International Economics, 13 (2), 283-297. doi: http://doi.org/10.1111/j.1467-9396.2005.00504.x

[7] Bal-Gunduz, Y., Ebeke, C., Hacibedel, B., Kaltani, L., Kehayova, V., Lane, C. et. al. (2013). The Economic Impact of IMF-Supported Programs in Low-Income Countries (No. 277). International Monetary Fund, 60. doi: http://doi.org/10.5089/9781484394717.084

[8] Reinhart, C. M., Rogoff, K. S. (2009). This time is different: Eight centuries of financial folly. Princeton: Princeton university press, 463.

[9] Evrensel, A. Y. (2005). IMF Programmes in Emerging Countries. Comparative Economic Studies, 47 (1), 4-22. doi: http://doi.org/10.1057/palgrave.ces.8100053

[10] Conway, P. (2007). The Revolving Door: Duration and Recidivism in IMF Programs. Review of Economics and Statistics, 89 (2), 205-220. doi: http://doi.org/10.1162/rest.89.2.205

[11] Aslund, A. (2012). How capitalism was built: the transformation of Central and Eastern Europe, Russia, the Caucasus, and Central Asia. Cambridge University Press, 440. doi: http://doi.org/10.1017/ cbo9781139207850

[12] Ukraine and the IMF Transactions with the Fund. International Monetary Fund. Available at: http://www.imf.org/external/country/UKR/index.htm

[13] Pro zbilshennia kvoty Ukrainy v Mizhnarodnomu valiutnomu fondi (2016). Rozporiadzhennia Kabinetu Ministriv Ukrainy No. 108-r 04.02.2016. Kabinet Ministriv Ukrainy. Uriadovyi kurier, 42.

[14] MVF. Mizhnarodne spivrobitnytstvo. Ministerstvo finansiv Ukrainy. Available at: http:// www.minfin.gov.ua/news/mizhnarodne-spivrobitnictvo/mvf

[15] Barro, R. J., Lee, J.-W. (2005). IMF programs: Who is chosen and what are the effects? Journal of Monetary Economics, 52 (7), 1245-1269. doi: http://doi.org/10.1016/j.jmoneco.2005.04.003

[16] Ivlieva, I. V. (2004). Rol Mizhnarodnoho valiutnoho fondu v makroekonomichnii stabilizatsii Yevropeiskykh tranzytyvnykh krain. Kyiv.

[17] Kushnirsky, F. (2014). Ukraine and The IMF: An Uneasy Cooperation. International Journal of Business and Social Research, 4 (7), 120-130.

[18] Materialy Derzhavnoi sluzhby statystyky Ukrainy. Available at: http://www.ukrstat.gov.ua/

[19] Richni zvity NBU za 1994-2017 rr. Natsionalnyi Bank Ukrainy. Available at: https://bank.gov.ua/ control/uk/publish/category?cat_id=58023

[20] Panchyshyn, S. M., Hrabynska, I. V. (2017). Pro typizatsiiu ta evoliutsiiu ekonomichnykh system. Biznes Inform, 8, 29-35. 